\title{
Anti-Cosmopolitanism and the Motivational Preconditions for Social Justice
}

(Forthcoming in Social Theory and Practice, vol. 43, no. 2, April 2017)

\section{Lior Erez ${ }^{1}$}

\begin{abstract}
This article reconstructs the political motivation argument against cosmopolitanism, according to which the extension of social justice beyond bounded communities would be motivationally unstable, and thus unjustified. It does so through an analysis of the stability problem, and a reconstruction of the three most prominent anti-cosmopolitan arguments Rawlsian statism, liberal nationalism, and civic republicanism - as solutions to this problem. It then examines, and rejects, three prominent objections, each denying a different level of the argument. The article concludes that the civic republican version of the argument is the most plausible, and implications for cosmopolitanism are considered.
\end{abstract}

Keywords: Civic Republicanism, Cosmopolitanism, Liberal Nationalism, Motivation, Stability, Rawls.

\footnotetext{
${ }^{1}$ Max Weber Postdoctoral Fellow, European University Institute, Via dei Roccettini, 9, 50014 San Domenico di Fiesole. Lior.erez@eui.eu.
} 
Cosmopolitanism about justice often faces the following objection. In order for a conception of social justice to be fully justified, it needs to be stable. For a conception of social justice to be stable, it must be able to motivate people to endorse it as regulative of their behavior, that is, as superior to their strategic, self-interested reasons. As this motivational precondition is not available globally, cosmopolitans' aspiration to globalize social justice would be unstable, and thus otiose. Importantly, the role that motivation plays in this argument is as a normative precondition for the justification of the cosmopolitan ideal, rather than merely as a constraint on its practical implementation which leaves the cosmopolitan ideal intact. The precise nature of this objection, however, remains unclear.

In this article, I address this gap by formulating and defending a version of this objection to cosmopolitanism, hereafter referred to as "political motivation argument" (PMA). I wish to demonstrate that, at least with regards to major versions of the motivational critique of cosmopolitanism, this argument is best construed as a response to the stability problem maintaining that any conception of social justice must be shown to be stable if it is to be fully justified. Following this thought, I reconstruct three versions of the PMA - Rawlsian statism, liberal nationalism, and civic republicanism - as responses to the stability problem, and argue that civic republicanism is the most plausible, both in comparison to alternative accounts, and in light of possible objections.

As a starting point, I suggest the following preliminary reconstruction of the PMA. At this stage, clearly, this general structure will leave some important questions unanswered. Nevertheless, I believe that it will also allow for a clear comparison between versions of the objection, as well as a better understanding of what, precisely, is under dispute between cosmopolitans and anti-cosmopolitans. What shall remain constant throughout is my reading of the particular version of cosmopolitanism about justice under attack: that is, cosmopolitanism as a normative, action-guiding theory, with a commitment to a concrete political ideal of the global order. The distinguishing feature of these accounts as cosmopolitan is that, whatever ideal of social justice they hold is justified within bounded societies, should be extended beyond them. This rather broad definition is meant to meet three desiderata. First, it is meant to be inclusive across different positions regarding the principles of social justice and the currency of justice. ${ }^{2}$ Second, it is meant to exclude those who are moral cosmopolitans in the weaker sense - i.e., who endorse universal moral equality without being committed to the globalization of social justice, even if some other normative standards apply globally. And finally, it aims to remain agnostic with respect to the particular institutional claims made by these cosmopolitans - for example, whether they argue in support of a world state; a federation of democratic republics; multi-layered, decentralized corporatism; or some other transformation of existing sovereign state-based world order. ${ }^{3}$

\footnotetext{
${ }^{2}$ Of course, cosmopolitan theorists hold diverse accounts of the principles of social justice and its extension beyond the state, including, but not limited to: a Global Difference Principle (e.g. Charles R. Beitz, Political Theory and International Relations (Princeton, NJ: Princeton University Press, 1979); Darrel Moellendorf, Cosmopolitan Justice (Boulder, CO: Westview Press, 2002).); Global Equality of Opportunities (e.g. Simon Caney, "Cosmopolitan Justice and Equalizing Opportunities," Metaphilosophy 32, no. 1-2 (2001): pp. 113-34); Global Basic Income (e.g. Philippe Van Parijs, "Basic Income for All," Boston Review 25, no. 5 (2000): pp. 48.). The general structure of my argument applies across these variations.

${ }^{3}$ For alternative definitions of cosmopolitanism, see the discussion in Samuel Scheffler, "Conceptions of Cosmopolitanism," Utilitas 11, no. 03 (1999), pp. 255-76; Thomas Pogge, "Cosmopolitanism," in A Companion to Contemporary Political Philosophy, ed. Robert E. Goodin, Philip Pettit, and Thomas W. Pogge, 2nd ed. (Malden, MA: Blackwell, 2007), pp. 312-32.
} 
In its general form, the PMA draws its conclusion from three premises and a factual claim:

\section{The Political Motivation Argument}

1. The Cosmopolitan Ideal: Cosmopolitanism about justice calls for the extension of the ideal of social justice beyond bounded societies.

2. The Motivational Precondition premise: the normative ideal of social justice requires, as a necessary precondition, a widespread disposition $\mathrm{M}$ among participants in the social scheme in order to be stable.

3. The Generating Feature premise: $\mathrm{M}$ is present and widespread among participants of a social scheme when it is generated by feature $\mathrm{F}$.

4. Factual Claim: The generating feature F does not, and cannot exist beyond bounded societies.

From 1-4, it follows that

5. The ideal of social justice cannot be stable beyond bounded societies, and so is not justified beyond bounded societies.

Therefore,

Conclusion: Cosmopolitanism is not fully justified.

In the rest of this article, I would turn to fill in the gaps of this general structure - the content of the motivational precondition $\mathrm{M}$ and the generating feature $\mathrm{F}$, the basis for the factual claim, and the nature of "bounded societies". These variables are understood differently by the three positions I reconstruct below.

My argument proceeds as follows. In the first section, I provide an account of the stability problem, which lies at the heart of the PMA, and is crucial for the validity of the argument. In the second and third section, I reconstruct the ways in which the three versions of the PMA I discuss address this problem, and how anti-cosmopolitan conclusions follow from them, first by addressing the deficiencies of the Rawlsian and nationalist accounts, and then turning to the preferred civic republican account. In the fourth section, I address three cosmopolitan objections, with each corresponding to a premise in the general structure of the argument. Properly understood, I argue that the political motivation argument, in its republican version, poses a serious challenge that cosmopolitans cannot afford to ignore. The upshot of my argument is that cosmopolitan theorists should either provide a suitable account of motivational stability, or hone up the radical conclusions of their own argument.

\section{The Stability Problem}


The starting point of this analysis is the stability problem, as articulated in Rawls's Theory of Justice and Political Liberalism. ${ }^{4}$ In Rawls's formulation, principles of justice are constructed in the original position by "artificial" persons, who, while ignorant of their own conception of the good, are able to make general assumptions regarding the nature of the good that they would want to pursue. As has been pointed out by several recent accounts, however, this stage is only a pro tanto justification of a conception of justice. ${ }^{5}$ For a conception of justice to be fully justified, it has to be shown that it would be stable, that is, that people with differing conceptions of the good will come to endorse it. ${ }^{6}$ The question of stability is not a problem to be dealt with later, once the right conception of justice has been chosen and justified. It is, rather, part of the justification process itself. ${ }^{7}$

In what way would any particular conception of justice fail to engender a desire to act upon it? The problem of stability arises when the two moral powers recognized by Rawls - the sense of justice and the rational pursuit of the good - are in conflict. This clash is inevitable because of the pluralist nature of different individuals' interests, what Rawls calls the "fact of pluralism" in liberal society. This pluralism is not a result of an unfortunate reality; it is rather "the natural outcome of the activities of human reason under enduring free institutions." ${ }^{8}$ Because of the burdens of judgment, i.e., the limitations on practical reason, even rational people acting in good faith will disagree in their moral and philosophical judgments.

Given the potential clash between the principles of justice and their interests, each individual in the well-ordered society is faced with what Rawls calls a "generalized prisoner's dilemma": while each could potentially maximize their interests by regulating their behavior in accordance with the principles of justice, each is faced with the temptation to defect, or free-ride, as to improve one's position at the expense of others.

This scenario could be represented with two social actors, A and B, and units of welfare. If A and $\mathrm{B}$ both cooperate, they will each receive 2 units, while mutual defection will result in one unit each. If A cooperates and B defects, A will receive nothing while B will get 3 units (the same logic applies when B cooperates and A defects). Defecting is the dominant strategy for any rational actor, since no matter what the other actor does, it is always rational to defect. Since both actors are rational, this results in the sub-optimal case of mutual defection being a dominant strategy.

[TABLE 1 HERE]

\footnotetext{
${ }^{4}$ John Rawls, A Theory of Justice (Harvard, MA: Harvard University Press, 1971) and Political Liberalism (Columbia University Press, 1993); Hereafter TJ and PL, respectively.

${ }^{5}$ For two influential recent accounts, see Samuel Freeman, "Congruence and the Good of Justice," in The Cambridge Companion to Rawls, ed. Samuel Freeman (Cambridge: Cambridge University Press, 2003), pp. 277315; Paul Weithman, Why Political Liberalism? On John Rawls's Political Turn (Oxford University Press, 2010).

${ }^{6}$ TJ, p. 145/125. [Page numbers for TJ references refer first to the original 1971 version, and then to the 1999 revised version, $16^{\text {th }}$ Edition.]

${ }^{7}$ Rawls writes that "A conception of justice "is seriously defective if the principles of moral psychology are such that it fails to engender in human beings the requisite desire to act upon it". TJ, p. 455/398.
}

${ }^{8}$ PL, p. xxiv. 


\begin{tabular}{|l|l|l|}
\hline & $\begin{array}{l}\text { B Makes Justice Regulative } \\
\text { (cooperate) }\end{array}$ & $\begin{array}{l}\text { B Decides Case-by-Case } \\
\text { (defect) }\end{array}$ \\
\hline A Makes Justice Regulative & 2,2 & 0,3 \\
\hline A Decides Case-by-Case & 3,0 & 1,1 \\
\hline
\end{tabular}

Table 1: Generalized Prisoner's Dilemma

Even if it could be shown that each individual would prefer everyone's actions to be regulated by the principles of justice, we are still faced with the problem of the "Assurance Game." In this scenario, unlike the prisoner's dilemma, each prefers mutual cooperation to self-interested defection, and prefers to comply, if all (or most) others comply. But since each prefers to defect if all others defect, rather than to suffer the costs of picking up the slack when others free-ride, the situation is still unstable unless all can be assured that others will cooperate.

[TABLE 2 HERE]

\begin{tabular}{|l|l|l|}
\hline & $\begin{array}{l}\text { B Makes Justice Regulative } \\
\text { (cooperate) }\end{array}$ & $\begin{array}{l}\text { B Decides Case-by-Case } \\
\text { (defect) }\end{array}$ \\
\hline A Makes Justice Regulative & 2,2 & 0,1 \\
\hline A Decides Case-by-Case & 1,0 & 1,1 \\
\hline
\end{tabular}

Table 2: Assurance Game

Unless some sort of mutual assurance is provided that others will not defect, people would prefer to reject the ideal of justice as regulative. The principles of justice will be unstable and thus, otiose. ${ }^{9}$

There are, therefore, two issues to be solved in order to secure the stability of the normative ideal of justice. First, that people will have an active sense of justice; and second, that the principles of justice will be regulative of people's behavior, i.e., that even when people are faced with the opportunity to defect they will not do so. In other words, it needs to be shown that it will be rational for people to grant justice a regulative status in their practical reasoning. In Rawls's terms, "the hazards of the generalized prisoner's dilemma are removed by the match between the right and the good", or, differently stated, between the reasonable and the

\footnotetext{
${ }^{9}$ Cf. the analysis in Weithman, Why Political Liberalism?, pp. 43-51.
} 
rational. ${ }^{10}$ The challenge for any account of justice, therefore, is to demonstrate how the right and the good will be matched, without relying on a fortunate contingency.

Note that this way of articulating the stability problem avoids two common misconceptions about Rawls's account. First, it is clear that the problem does not belong to the realm of nonideal theory: i.e., it does not ask how we get non-compliant citizens to comply with justified conceptions of justice in the actual social world. ${ }^{11}$ Second, some of Rawls's readers assume that, since the stability problem is discussed within ideal theory, it is resolved with the introduction of the sense of justice. ${ }^{12}$ In Rawls's moral psychology, however, the desire to do what is just is conditional upon the knowledge that others would reciprocate; a conception of right does not have independent motivating power, unrelated to any rational ends, as this cannot account for any reason-giving power of the sense of justice, and the decision to make justice regulative of other desires becomes arbitrary. ${ }^{13}$ Importantly, even if the sense of justice has some motivating power, it needs to be shown that it will be regulative of people's conceptions of the good in order to solve the assurance problem. ${ }^{14}$

\section{Reconstructing the Rawlsian and Liberal Nationalist Solutions}

With this understanding of the stability problem, I now turn to consider two dominant versions of the PMA: Rawlsian statism and liberal nationalism. The purpose of this section is twofold. First, I will argue that these accounts are structurally similar, and could be plausibly read as solutions to the stability problem. Second, by considering these accounts as solutions to the stability problem, I will demonstrate the deficiencies of the Rawlsian and nationalist accounts, and the need for a plausible alternative.

\subsection{Rawlsian statism}

In Rawls's original solution to the stability problem in Part III of TJ, he argued that rational members of the well-ordered society would view themselves as free and equal moral persons, and would have a desire to express their nature as such by acting upon principles of justice. ${ }^{15}$ In $P L$, however, Rawls states that relying on this argument is problematic, as "it is not consistent with the view as a whole". ${ }^{16}$ The problem is that the argument fails to appreciate the extent of the fact of pluralism. If pluralism is the result of free institutions, then a reliance on any particular conception of the good to solve the stability problem simply begs the question.

\footnotetext{
10 TJ, p. $577 / 505$.

${ }^{11}$ For a recent (otherwise convincing) example, see Naima Chahboun, "Nonideal Theory and compliance-A Clarification," European Journal of Political Theory 14, no. 2 (2015), pp. 229-245. As Rawls explicitly states, in describing the stability problem, we are "...still limiting ourselves to strict compliance theory." (TJ, pp. 513514/450).

${ }^{12}$ For this assumption see, for example, Brian Barry, "John Rawls and the Search for Stability," Ethics 105, no. 4 (1995), pp. 874-915 at pp. 885-886.

13 TJ, pp. 478/419.

${ }^{14}$ Pace Barry, "John Rawls and the Search for Stability," pp. 883-884; cf. Freeman, "Congruence and the Good of Justice,” pp. 281-283, 286-289; Weithman, Why Political Liberalism?, p. 126.

15 TJ, p. 252/222; See Freeman, “Congruence and the Good of Justice,” pp. 290-297 and Weithman, Why Political Liberalism?, Ch. 7 (and particularly pp. 184-189), on this so-called "Kantian Congruence Argument”.

${ }^{16}$ PL, p. xvi.
} 
Rawls's response was to move from the moral to the political: what maintains stability is not a comprehensive moral doctrine, but a shared conception of the citizen, compatible with various reasonable conceptions of the good. Rawls argues that by sharing a political culture, each individual could affirm this shared conception from her own moral lights. For liberals this would be an easier task, but other citizens could affirm the political conception from their own substantive reasons. Thus, in the well-ordered society, different reasonable conceptions of the good would converge on a shared political conception. ${ }^{17}$

This, so far, is familiar territory. What I argue here is that Rawls's anti-cosmopolitan position in Law of Peoples can be understood through his solution to the stability problem in Political Liberalism. The merit of this reading, I believe, is that it demonstrates a coherence in Rawls's writing and explains the foundation of his anti-cosmopolitanism. ${ }^{18}$ While there may be alternative explanations for Rawls's anti-cosmopolitanism, I argue that it is a plausible way to interpret the implications of his account the question of global justice. ${ }^{19}$

To understand this move, it is important to see that for Rawls, the political solution to the stability problem is not a claim about individual desires and motivations - that is, each person's idiosyncratic moral identity - but is based upon a shared political culture. Through such political culture, the conception-based desire to be a certain kind of citizen is brought into people's subjective motivational sets, albeit in an indirect and informal manner. ${ }^{20}$ Without it, there will be no overlapping consensus among reasonable citizens on the conception of the citizen, and thus no basis for reasonable agreement. In that case, there will be no assurance that, at least generally, other citizens will act as justice requires and will not free-ride, and such a society would not be stable.

The society of which citizens are members is conceived of as "self-contained and as having no relations with other societies" 21 , and as such there is no global public culture to provide a shared conception of the citizen. Individuals would therefore not be motivated to make justice regulative of their public action, because they would lack the assurance that others would do the same. The missing motivational precondition is therefore a constraint on any account of global justice that seeks to globalize the original position, and Rawls considers it a fatal one

\footnotetext{
${ }^{17}$ See Freeman, "Congruence and the Good of Justice," p. 307.

${ }^{18}$ For stability interpretations of LoP, see Leif Wenar, "Why Rawls Is Not a Cosmopolitan Egalitarian," in Rawls's Law of Peoples: A Realistic Utopia?, ed. Rex Martin and David A. Reidy (Malden, MA: Blackwell, 2006), pp. 95-113, and Hyunseop Kim, “A Stability Interpretation of Rawls's The Law of Peoples," Political Theory 43, no. 4 (2015), pp. 473-499. In his recent book, Aaron James advances a critique of cosmopolitanism which relies on an interpretation of the problem of assurance, albeit leading to different conclusions. Fairness in Practice: A Social Contract for a Global Economy (Oxford: Oxford University Press, 2012), pp. 103-31.

19. Textual support for my reading is cited in Katrina Forrester, "Citizenship, War and the Origins of International Ethics in American Political Philosophy 1960-1975," The Historical Journal 57, no. 3 (2014): pp. 773-801 at p. 789 fn53.

${ }^{20}$ PL, pp. 107-110.

${ }^{21}$ PL, p. 12.
} 
for cosmopolitan positions that seek to extend his domestic theory of justice. They are not, in other words, realistic utopias. ${ }^{22}$

This reflects the premises given by the general structure of the PMA, whose Rawlsian version takes the following form:

1. Cosmopolitanism about justice calls for the extension of the ideal of social justice beyond the boundaries of well-ordered societies.

2. The ideal of social justice requires, as a necessary precondition for its stability, a widespread sense of mutual trust (M) among participants in the social scheme to assure them that others will comply.

3. A sense of mutual trust is present in bounded societies as a consequence of a shared political conception of the citizen $(\mathrm{F})$ that members of well-ordered societies share, as a result of their political culture.

4. There is no shared political culture, and thus no shared political conception of the citizen, beyond the boundaries of well-ordered societies.

From 1-4, it follows that

5. The ideal of social justice cannot be stable beyond the boundaries of well-ordered societies.

Therefore, given the stability problem

Conclusion: Cosmopolitanism is not fully justified.

Note that, by denying the existence of a global shared conception of the citizen, Rawls is not denying the existence or desirability of certain international norms, which may well derive from a "global political culture" in a broader sense. This explains, for example, why international norms such as the duty to assist burden societies do not generate motivational concerns for him, even when he recognizes that the lack of affinity between peoples may pose some practical constraints for implementation. ${ }^{23}$ Similarly, certain norms of justice between peoples (most importantly those related to trade and warfare) achieve their stability in a process analogous to that described in PL. ${ }^{24}$ Yet Rawls is explicit that these norms are different from those governing the relations of social justice between citizens within a well-ordered society, with global "political culture" regulating the behavior of peoples, rather than individuals.

Nevertheless, as many of Rawls's critics have rightly pointed out, this version of the PMA seems arbitrarily statist. Rawls merely stipulates that the political conception of the citizen is

\footnotetext{
${ }^{22}$ As he writes, “... I draw on a psychological principle that social learning of moral attitudes supporting political institutions works most effectively through society-wide shared institutions and practices... In a realistic utopia this psychological principle sets limits to what can sensibly be proposed as the content of the Law of Peoples" John Rawls, The Law of Peoples (Harvard University Press, 2001), p. 112 fn.44. [hereafter LoP]

${ }^{23}$ LoP, pp. 112-113. In thank an anonymous reviewer for pointing out this particular challenge.

${ }^{24}$ LoP, pp. 44-54, with reference to the stability of democratic peace.
} 
limited to within the borders of the territorial state, yet he does not substantiate this fundamental claim, either empirically or normatively. ${ }^{25}$ Onora O'Neill famously argued that Rawls in assuming an idealized closed society, while "it is all too well known that in real life persons are often unsure about their sense(s) of political identity, that they may find that those with whom they live in closed societies are not identical with those whom they regard as their own people, and that not all societies are closed". ${ }^{26}$ In the global context, this becomes particularly problematic: given that the role of idealization in Rawls's framework was to abstract from morally irrelevant features of individuals, introducing state borders into ideal theory seems to betray a fundamental commitment.

Furthermore, Rawls's account with regards to the nature of public culture and the shared conception of the citizen is suspiciously weak. Given that it is focused on an allegiance to public reason and their honouring of the duty of civility ${ }^{27}$, the Rawlsian conception of the citizen is taken to be too abstract to motivate public spiritedness among members of a political society, specifically when it endorses a strict private-public distinction between the public conception of justice and the private conceptions of the good. ${ }^{28}$ This is exacerbated with Rawls's inconsistency with regards to the nature of citizenship and political society: At points, he is insistent that a political society is not a community, as members do not share a common end, but merely converge on some shared public interest; yet elsewhere, he maintains that the public conception of the citizen requires sharing a common political end, thus blurring the distinction between a comprehensive community and political society as a "union of social unions". ${ }^{29}$

These two deficiencies suggest a tension in Rawls's position, both as a critique of cosmopolitanism and as a solution to the stability problem. In other words, Rawls's account of public culture in his version of the PMA is incomplete: it has to specify why a shared political culture is bounded to a specific society in particular, and could not be considered globally; and it has to show that the public conception of the citizen would be thick enough to overcome the stability problem. The liberal nationalist and civic republican versions, to which I turn next, can be read as working within the general framework of the Rawlsian version, while providing a thicker description of the public conception of the citizen.

\subsection{Liberal nationalism}

\footnotetext{
${ }^{25}$ See for example Onora O’Neill, "Political Liberalism and Public Reason: A Critical Notice of John Rawls, Political Liberalism," The Philosophical Review 106, no. 3 (1997), pp. 411-428; Thomas Pogge, “An Egalitarian Law of Peoples", Philosophy and Public Affairs, 23 (1994), pp. 195-224; Andrew Kuper, "Rawlsian Global Justice: Beyond the Law of Peoples to a Cosmopolitan Law of Persons", Political Theory, 28 (2000), pp. 640-74.

${ }^{26}$ O’Neill, pp. 419-420.

${ }^{27}$ PL., p. 485.

${ }^{28}$ Andrés De Francisco, “A Republican Interpretation of the Late Rawls,” Journal of Political Philosophy 14, no. 3 (2006): pp. 270-288; G. A. Cohen, Rescuing Justice and Equality (Cambridge, MA: Harvard University Press, 2008), pp. 183-96.

${ }^{29}$ See Richard Dagger, "Citizenship as Fairness: John Rawls's Conception of Civic Virtue” in A Companion to Rawls, ed. Jon Mandle and David A. Reidy (Chichester: Wiley-Blackwell, 2013), pp. 297-312 at p. 308.
} 
The liberal nationalist argument against cosmopolitanism could be understood as arising from concerns about motivational stability, structurally similar to the Rawlsian version. ${ }^{30}$ There are, however, two considerable differences between the standard Rawlsian and nationalist accounts.

First, the necessary motivation identified by the nationalist account is thicker: liberal nationalists argue that not only mutual trust, but solidarity is "crucial for the functioning of a liberal state in general, and a liberal welfare state in particular." 31 Solidarity is interpreted here as a motivational precondition consists in "members [giving] each other's interests some noninstrumental weight in their practical reasoning". ${ }^{32}$ This captures the sense in which solidarity is not merely the overlapping of individual interests, but denotes also the willingness to sacrifice personal gains for the collective good. Limiting social justice to what can regulate reciprocal relations of mutual interest will fail to capture what is valuable about the welfare state. Any account that explains the welfare state without relying on solidarity, it is argued, either cannot explain its existence, or is implicitly assuming solidarity. ${ }^{33}$ This takes a similar form to G.A Cohen's critique of Rawls, and his proposal of a socialist ethos that will noncoercively redirect the well-off to restrict their anti-egalitarian demands. ${ }^{34}$ The logic of the liberal nationalist PMA is similar, although clearly the precise nature of the ethos advocated is different. $^{35}$

The second element of the liberal nationalist PMA, which is crucial for its anti-cosmopolitan conclusions, is that the motivational precondition can only be stably generated by a shared national identity, which does not have a global equivalent. While this is sometimes conflated with the first point, it is crucial to separate here the question of (i) what is the required motivation (trust and solidarity), and second (ii) what generates this motivation (national identity). Indeed, as I will demonstrate below, it is possible to accept that solidarity is a motivational precondition for social justice without accepting that a shared national identity is the only way in which it could come about. For the liberal nationalist PMA, however, whether we think that this motivational precondition is captured by the thicker conception of solidarity or by the thinner conception of social trust, these dispositions could only be stably generated by a shared national identity.

The liberal nationalist PMA, then, takes the following form:

1. Cosmopolitanism about justice calls for the extension of the ideal of social justice beyond the boundaries of national communities.

\footnotetext{
30. For a similar comparison between the Rawlsian stability argument and the liberal nationalist argument, see Jonathan Seglow, "Universals and Particulars: The Case of Liberal Cultural Nationalism," Political Studies 46, no. 5 (1998), pp. 963-977 at pp. 970-971. Against this comparison, see Sune Lægaard, "Feasibility and Stability in Normative Political Philosophy: The Case of Liberal Nationalism," Ethical Theory and Moral Practice 9, no. 4 (2006): pp. 399-416.

${ }^{31}$ Yael Tamir, Liberal Nationalism (Princeton, NJ: Princeton University Press, 1993), p. 96.

${ }^{32}$ Andrew Mason, Community, Solidarity and Belonging: Levels of Community and Their Normative Significance (Cambridge: Cambridge University Press, 2000), 27.

${ }^{33}$ David Miller, "Nationality: Some Replies,” Journal of Applied Philosophy 14, no. 1 (1997), pp. 69-82 at p. 70.

34 Cohen, Rescuing Justice and Equality, pp. 183-196.

35 Tamir, Liberal Nationalism, p. 121; see also Margaret Canovan, Nationhood and Political Theory (Northampton, MA: Edward Elgar Publishing, 1998), p. 28.
} 
2. The ideal of social justice requires, as a necessary precondition, a widespread sense of trust and solidarity (M) among participants in the social scheme.

3. The necessary sense of trust and solidarity is present in national communities, as a consequence of the national identity (F) members of these societies share.

4. There is no equivalent for a national identity beyond the boundaries of national communities.

From 1-4, it follows that

5. The ideal of social justice cannot be stable beyond national communities.

Therefore, given the stability problem,

Conclusion: Cosmopolitanism is not fully justified.

One clear advantage of this position is that, in contrast with the abstract Rawlsian account of public culture, it seems clear that there is no global equivalent for national identity. Of course, to claim that national identity only exists within national communities is almost trivial. The precise account of national identity must be unpacked, so it can be shown to be both sufficiently particularist and plausibly generate the required motivational disposition. Unfortunately, the three common liberal nationalist answers to this question suffer from considerable deficiencies.

The first possibility is to interpret national identity as a group identity, that is, to view national membership as equivalent to other involuntary associations which generate a sense of commitment and solidarity, first and foremost the family. ${ }^{36}$ This sense of commitment does not depend on any particular ethical value of these relationships; I may be in radical disagreement with my brother about fundamental issues, yet our familial relationship, insofar as it is part of my practical identity, would still generate a sense of concern for him. This account, however, is highly problematic; unless implausibly strong assumption about kinship and the place of national identity in the lives of individuals are accepted, the analogy between family and nation does not hold. ${ }^{37}$

The second account of national identity tracks trust to a shared societal culture. ${ }^{38}$ First, sharing a language and cultural background facilitates communication between citizens, which mitigates epistemic barriers to trust; second, sharing a common culture and norms with others - including norms of incentives and punishment - makes their behavior more predictable to us, and therefore lowers the threshold for trusting that others would do as we expect. Shared cultural norms are of course not sufficient for trust - I may distrust you precisely because we

\footnotetext{
${ }^{36}$ A version of this claim may be found in Thomas Hurka, "The Justification of National Partiality," in The Morality of Nationalism, ed. Robert McKim and Jeff McMahan (Oxford: Oxford University Press, 1997), 13958; David Miller, On Nationality (Oxford: Oxford University Press, 1995), p. 3. Note that my discussion here does not address the question of whether these relationship generate associative obligations, only whether they generate the right kind of motivation.

${ }^{37}$ See for example Jeff McMahan, "The Limits of National Partiality," in McKim and McMahan (eds.), The Morality of Nationalism, pp. 107-38.

${ }^{38}$ Will Kymlicka, Multicultural Citizenship: A Liberal Theory of Minority Rights, New Ed edition (Oxford; New York: Clarendon Press, 1995), p. 76.
} 
share these norms and I believe you violate them. But they are nevertheless, in this account, close to being a necessary condition. ${ }^{39}$ However, this account is deficient as a solution to the stability problem: a societal culture does not necessarily give members a reason to see social justice as regulative of practical reasoning, even less to grant others who share their societal culture a non-instrumental place in their reasoning.

The third account seeks to transcend the problems of the above views, by interpreting national identity as representing valuable ethical relationships between members of the national community, and viewing trust as a product of this pursuit of a shared good. Members of a national community view this shared identity as a pre-political common good, and this in turn generates certain special obligations between them, not least the obligation to promote and sustain this shared identity. ${ }^{40}$ The value of this shared identity might be interpreted in a contextualist way, constituted by the shared belief in it, or based on some objective grounds. ${ }^{41}$ If we have a reason to believe that fellow-citizens share a commitment to the promotion of a common good, then we have a prima facie reason to trust their motives and actions. As fellow nationals, we might disagree on the ways to promote this good, but our disagreement is contained within the broader meta-consensus on what our shared good is. ${ }^{42}$

This view of national identity is more successful than the first two at providing an ethical basis for solidarity without the pitfalls of the family analogy. Yet it remains deficient on two accounts. First, empirically speaking, the link between a strong national identity and robust institutions of social justice is contingent at best. ${ }^{43}$ Liberal nationalists may, of course, contain this charge by pointing out that the shared conceptions of good may be plural between communities. Indeed, there is nothing in this account that necessitates any particular view on social justice, and the sense of national identity is seen only a necessary condition, but not a sufficient one. Given the nature of the stability problem, however, this answer is less than satisfactory; it seems to achieve stability through a social ideal which is in itself external to the conception of social justice.

Even if the liberal nationalist is able to accommodate this concern, a more troubling point is that the boundaries of national communities and the borders of the state are rarely congruent. Following the logic of the argument, this would lead us to the conclusion that, implausibly, the ideal of social justice cannot be stable within multinational states, and could be stable for national communities across borders. ${ }^{44}$ A plausible liberal nationalist argument must either broaden the definition of national identity to fit the boundaries of the nation-state, argue that multinational states are prone to secession, or, more commonly, maintain different cultural affiliations are "nested" within a larger, encompassing national identity. ${ }^{45}$ This latter route is

\footnotetext{
${ }^{39}$ Miller, On Nationality, pp. 92-94.

${ }^{40}$ Ibid., 188.

${ }^{41}$ Respectively: Miller, On Nationality; Hurka, “The Justification of National Partiality”; cf. Margaret Moore, The Ethics of Nationalism (Oxford University Press, 2001), pp. 26-41.

${ }^{42}$ For a similar analysis, see Matthew Festenstein, "National Identity, Political Trust and the Public Realm," Critical Review of International Social and Political Philosophy 12, no. 2 (2009): pp. 279-296 at p. 284.

${ }^{43}$ See David Miller and Sundas Ali, “Testing the National Identity Argument," European Political Science Review 6, no. 2 (2014): pp. 237-59.

${ }^{44}$ Moore, The Ethics of Nationalism, pp. 94-98.

${ }^{45}$ David Miller, Citizenship and National Identity (Cambridge: Polity, 2000), pp. 127-132.
} 
promising, but it comes at a cost: the way in which co-nationals share a common identity, and the cultural elements relevant to this identity, become much more restricted.

\section{The Civic Republican Alternative}

With the respective deficiencies of the Rawlsian and liberal nationalist accounts in mind, we can now turn to the third version of the PMA, which draws on the civic republican tradition. The civic republican argument, I argue, mitigates the flaws of the Rawlsian and liberal nationalist accounts identified above, and could be read as an improved, more plausible version of both.

A common reading of civic republicanism is as an alternative to liberal political morality. ${ }^{46}$ Against the liberal focus on liberty as non-interference, civic republicans have placed their emphasis on liberty as freedom from domination by an arbitrary power, both public and private. This conception of liberty as non-domination as a primary good has led republicans to prefer constitutional institutions and a more engaged mode of citizenship as an antidote to the abuse of political power by corrupt elites. While the liberal conception of the citizen is thought of as a nexus of rights, which are construed in a negative manner, republican citizenship is a status that carries with it more stringent positive duties. It is thus more demanding of the individual citizen - it requires that people not only avoid harm to others and obey the law, but willingly share in practices of social cooperation and make considerable compromises and sacrifices for the sake of the common good of being not dominated.

Accordingly, civic republicanism demands strong ties of obligation and solidarity among citizens who maintain each other's freedom from domination. Yet unlike the liberal nationalist version, these strong ties are not the result of pre-political identification with other members of the community. Rather, this is an allegiance to a certain political way of life, or a "love of country", a sense of "belonging to a polity", in which citizens see the flourishing of institutions and practices as linked to their own political freedom. ${ }^{47}$ Citizens in a republican polity are linked by sense of collegiality, and are perceived as sharing a common political good of nondomination. ${ }^{48}$

The motivational precondition here is not a particular motivation, but rather a cluster of motivations grouped under "civic virtue". Citizens are to be motivated to (a) resist being dominated by an arbitrary power, (b) avoid dominating others, and (c) protect others from nondomination by third parties. In other words, for the normative ideal of social justice, understood here as non-domination, to be stable, citizens must see acting by civic virtues as regulative of the other desires and interests they may have, and, crucially, trust that other citizens are doing the same. While virtuous citizens must be vigilant against the abuse of trust by political

\footnotetext{
${ }^{46}$ See Cécile Laborde and John Maynor, eds., Republicanism and Political Theory (Oxford: Blackwell, 2008).

${ }^{47}$ Mason, Community, Solidarity and Belonging, p. 127.

48 See for example Iseult Honohan, "Friends, Strangers or Countrymen? The Ties between Citizens as Colleagues," Political Studies 49, no. 1 (2001): pp. 51-69
} 
institutions and fellow-citizens, the role of trust in institutions and fellow-citizens is crucial for maintaining the practices of republican citizenship. ${ }^{49}$

One may object, at this point, that this account of civic motivation is overly abstract and unrealistic. Unlike appeals to constitutional essentials or national identity, which are a familiar features of actual political discourse, can we really expect citizens to be motivated by such high-minded ideals as non-domination $?^{50}$ As a matter of fact, however, opposing domination and resisting arbitrary power are very common and effective tropes in the rhetoric of political parties and movements, both historically and presently. Consider the following examples. National liberation movements' appeal not only to a shared cultural identity, but to the value of self-determination and resistance to foreign rule. Ideals of non-domination were also prevalent in abolitionist and anti-apartheid rhetoric, powerfully captured in Nelson Mandela's famous 1964 speech during the Rivonia trial, where he describes the struggle against white and black domination as an ideal worth dying for ${ }^{51}$; And finally - though with obviously far less world historical significance - the success of the recent campaign for the United Kingdom leave of the European Union ("Brexit") was attributed, to a large degree, to the rhetorical power of "taking control" back from political elites and Brussels bureaucrats. The validity and desirability of each of these particular arguments may be questioned, of course, but not so much their motivational efficacy.

But how can civic virtue and citizens' trust in the motives of fellow-citizens be sustained beyond such specific and unusual circumstances? Different republican accounts provide competing answers to this question. In so-called "Athenian" or "civic humanist" versions of republicanism, man is perceived as essentially a social and political animal. Civic virtue is thus seen as the highest rational good for the individual, and the congruence between the personal good and the regulative role of civic virtue is secured. The common good is understood as prepolitical, embedded either in the basic human good of sociability, or in a particular way of life and a shared identity as an ethical community. ${ }^{52}$

Historically, republicans such as Montesquieu and Rousseau, as well as some of their critics, have argued that this view of civic virtue cannot be advanced in modern nation-states, and is restricted to smaller polities, such as the Greek polis or the city-states of the Renaissance. ${ }^{53}$ In

\footnotetext{
49 A related analysis of the role of civic virtue as a republican solution to the stability problem can be found in Lovett, "Machiavelli, Civic Virtue, And the Problem of Stability" [paper presented at the APSA 2013 Annual Meeting].

50 This objection has been put forward to me, on separate occasions, by Paul Sagar as well as an anonymous reviewer. It is also a common liberal critique of republicanism more generally, for example in Geoffrey Brennan and Loren Lomasky, “Against Reviving Republicanism,” Politics, Philosophy \& Economics 5, no. 2 (2006): pp. 221-52.

${ }^{51}$ Nelson Mandela, “..I am Prepared to Die”, (11 June 1964). Transcript found in the British Library Magna Carta Collection, http://www.bl.uk/collection-items/nelson-mandelas-speech-i-am-prepared-to-die-at-the-rivonia-trial [accessed 22nd July 2016]

${ }^{52}$ See for example Michael Sandel, "The Procedural Republic and the Unencumbered Self," Political Theory 12, no. 1 (1984), pp. 81-96; Charles Taylor, "Why Democracy Needs Patriotism," in For Love of Country: Debating the Limits of Patriotism, ed. Martha Nussbaum and Joshua Cohen (Beacon Press, 1996), pp. 119-21.

${ }^{53}$ Montesquieu, The Spirit of the Laws [1748], trans. Anne M Cohler, Basia C Miller, and Harold Stone (Cambridge University Press, 1989). For an excellent account of these debates in the $18^{\text {th }}$ and $19^{\text {th }}$ Century, see Jacob T. Levy, "Beyond Publius: Montesquieu, Liberal Republicanism and the Small-Republic Thesis," History of Political Thought 27, no. 1 (2006): pp. 50-90.
} 
response, some liberal nationalists, sympathetic to republican citizenship, argue that under the conditions of modernity civic virtue can only be maintained through a cultural national identity. ${ }^{54}$ According to this argument, nation-states are the only political units large enough to sustain a modern political system, while at the same time maintaining a shared identity as a resource of civic virtue. As we saw above, however, this account faces the problem of the incompatibility between cultural national identities and political boundaries.

To avoid this problem, civic republicans maintain that the link between nationalism and civic patriotism is historically contingent. The common good is seen not as an objective pre-political good, but as the result of democratic interpretation. ${ }^{55}$ Insofar as civic republicanism has an account of a shared collective identity, it interprets this identity as a public culture of particular political traditions, practices and histories. Thus unlike the ethical community account, the shared view of the good is not a pre-political given, nor is it meant to be seen as fully encompassing of any individual ethical identity. The political culture of the well-ordered republican polity maintains the civic virtue of citizens through the socialization into the political norms of non-domination, albeit in their particular form within the local political tradition, social norms, cultural traditions, and historical examples. ${ }^{56}$

The structural similarity of this account to the Rawlsian one should not be surprising. Rawls explicitly states that his political liberalism is fully compatible to non-perfectionist versions of republicanism, and recent contributors to the debate have pointed to strong affinities between these accounts. ${ }^{57}$ The interpretation of Rawls as a civic republican can only go so far, however. As I pointed out above, Rawls is indeterminate and abstract about the nature of the political public culture, to a point where it is not clear whether his account can indeed serve as a solution to the stability problem. As De Francisco notes in a recent critique, Rawls's motivational dualism, in which "the motivation for social justice (what prompts citizens to exhibit civic virtue) is different from, and independent of, the motivation for the creation and pursuit of the private good" is too weak to account for the level of civic participation required to maintain political freedom. ${ }^{58}$ Civic republicanism, on the other hand, embeds both private and public motivation in a shared interest of non-domination, and is therefore less susceptible to this charge.

The PMA now takes the following form:

\footnotetext{
${ }^{54}$ See for example David Miller, "Republicanism, National Identity and Europe," in Republicanism and Political Theory, ed. Cécile Laborde and John Maynor (Oxford: Blackwell, 2008), pp. 133-158 at p. 148.

55 Philip Pettit, Republicanism: A Theory of Freedom and Government (Oxford; New York: Oxford University Press, 1997), chapter 6; See also Richard Bellamy, Political Constitutionalism: A Republican Defence of the Constitutionality of Democracy (Cambridge: Cambridge University Press, 2007).

${ }^{56}$ Maurizio Viroli, For Love of Country: An Essay on Patriotism and Nationalism (Oxford University Press, 1995); Cécile Laborde, "From Constitutional to Civic Patriotism," British Journal of Political Science 32, no. 04 (2002), pp. 591-612.

${ }^{57}$ PL, 205; Justice as Fairness, 142. See for example Richard Dagger, Civic Virtues: Rights, Citizenship, and Republican Liberalism (New York, NY: Oxford University Press, 1997), pp. 186-190, and his "Citizenship as Fairness"; Andrés De Francisco, "A Republican Interpretation of the Late Rawls", pp. 270-88; contra Maurizio Viroli, Republicanism (New York: Hill and Wang, 2002), p. 61.

${ }^{58}$ De Francisco, “A Republican Interpretation of the Late Rawls”, pp. 283-287.
} 
1. Cosmopolitanism about justice calls for the extension of the ideal of social justice beyond the boundaries of republics.

2. The ideal of social justice requires, as a necessary precondition, a widespread sense of civic virtue (M) among citizens.

3. The necessary sense of civic virtue is present in well-ordered republics as a consequence of a historically situated political culture $(\mathrm{F})$.

4. There is no equivalent for a shared political culture beyond the boundaries of wellordered republics.

From 1-4, it follows that

5. The ideal of social justice cannot be stable beyond the boundaries of republics.

Therefore, given the stability problem,

Conclusion: Cosmopolitanism is not fully justified.

This version, I argue, is the most plausible among the three accounts of the PMA. It supplements the Rawlsian account with the necessary explanation for the particularity of the political culture, without reducing it to cultural affinity as in some versions of liberal nationalism.

It is important to note, however, that civic republicanism is not inherently antagonistic to cosmopolitanism. Indeed, some recent theorists have drawn upon the republican conception of social justice as the reduction of domination to support cosmopolitan accounts of global justice. ${ }^{59}$ The anti-cosmopolitanism of the republican solution to the stability problem is, therefore, not self-evident. Moreover, a republican rejection of a cosmopolitan theory of justice does not entail a rejection of all normative accounts of international justice between political communities, for the same reason that a Rawlsian rejection of a cosmopolitan theory of justice is consistent with endorsing the Law of Peoples.

Nevertheless, I wish to argue here that if my interpretation of the civic republican solution is accurate, and given the absence of a global political culture equivalent to that which exists within republics, at least three concerns should be raised among civic republicans with regards to justice-based cosmopolitanism.

The first worry is that, absent a global political culture, a cosmopolitan ideal of social justice would require unrealistic levels of altruism. As Pettit writes in his "Republican Law of Peoples", the cosmopolitanism ideal would be utopian

\footnotetext{
59 See for example James Bohman, "Republican Cosmopolitanism" Journal of Political Philosophy 12, no. 3 (2004): pp. 336-352; Samantha Besson and José Luis Martí, Legal Republicanism: National and International Perspectives (Oxford: Oxford University Press, 2009).
} 
...in the sense that states, in particular the richer representative states, would have to be saintly - in effect, they would have to be controlled by saintly peoples - in order to provide robustly for the satisfaction of the ideal. The world in which states operated like that would be a more perfect world than ours but psychological and institutional realities make it into a scenario we can hardly rely on being able to attain. ${ }^{60}$

Pettit does not specify here why cosmopolitan justice, but not social justice within the state, would require unrealistic levels of altruism. In more recently published work, however, there are some clues that, importantly, point in the direction of the PMA. First, Pettit sees state sovereignty as a necessary condition for non-domination, as it reflects the self-determination of a democratic people. Since trust is in short supply across cultural divides, there will be "less likelihood of establishing those important unelected authorities... who could credibly claim to make decisions in line with shared standards", and thus "the cause of democracy, articulated in terms of freedom, argues for a world of many states." ${ }^{61}$ Following this thought, Pettit argues that states are obliged not to use their citizens' tax revenue towards the needs of other people "except when those citizens explicitly or implicitly demand this, or support it as an implication of a separate demand." 62 Given the motivational limits on social justice, the cosmopolitan ideal is realizable only if people become more other-regarding than they currently are - in other words, assuming away the stability problem - or if political institutions act against their people's expressed will.

The second and related concern is that cosmopolitan ideals of justice would require global political institutions for their creation and implementation, and these, in turn, risk becoming themselves sources of domination and arbitrary power. The danger lurks in the lack of a global equivalent of active citizenship, which in the civic republican account carries a motivational precondition of civic virtue and a sense of belonging to a polity. Without a political culture and tradition to provide the motivation to engage and criticize these political institutions, there is a risk of them operating against the democratic will of the people. This, correspondently, will have a negative effect on citizens' trust towards allegiance to these institutions, seeing them as alien dominating forces rather than a representation of the democratic will. ${ }^{63}$

Note that this republican concern need not assume that the ideal of cosmopolitan justice requires a global leviathan. Indeed, many, if not most contemporary cosmopolitans explicitly reject the notion that their theories require the establishment of a global equivalent to the sovereign state, and restrict their prescriptions to global institutions addressing specific policy areas (for example, taxation, migration, or development policies). ${ }^{64}$ Nevertheless, insofar as cosmopolitan ideals of justice are meant to be serve as a stable foundation for political action, and not merely as voluntary guidelines for sovereign states, they would require at least some

\footnotetext{
${ }^{60}$ Philip Pettit, “A Republican Law of Peoples,” European Journal of Political Theory 9, no. 1 (2010), pp. 70-94 at p. 86 .

${ }^{61}$ Philip Pettit, Just Freedom: A Moral Compass for a Complex World (New York, NY: W. W. Norton \& Company, 2014), p. 158.

${ }^{62}$ Ibid., p. 184. Pettit believes that the ideal of non-domination between self-determining states is a more incentivecompatible, and thus a more motivationally stable ideal.

${ }^{63}$ Ibid., 169-170.

${ }^{64}$ Although it may be doubtful whether these positions are coherent; see for example Luke Ulaş, "Transforming (but Not Transcending) the State System? On Statist Cosmopolitanism," Critical Review of International Social and Political Philosophy, (forthcoming).
} 
of these supra-national institutions to have political authority over the relevant domains. Given that republicans question the existence of a global public culture that would facilitate civic engagement with these institutions, the worry with regards to domination is not unfounded even if we restrict the authority of these institutions to specific policy areas: consider, for example, the political power held by the World Trade Organization over weak states.

A third and final concern is that the diffusion of patriotic concern for compatriots would have negative consequences for the relationship between citizens. As Richard Miller argues, extending the relationship of civic friendship globally would undermine the relationship of trust among citizens. Miller interprets the cosmopolitan ideal of justice as allowing no partiality towards one's compatriots, and thus the needs of more needy foreigners take precedence. As the disadvantaged citizens of a political society no longer see their compatriots as committed to their protection from domination, and since there is a "psychologically inevitable limit" on the levels of trust and respect in a domestic society without this special concern between compatriots, this will undermine the basis for cooperation in society and will generate forms of objectionable domination. ${ }^{65}$

These three concern are not, of course, knock-down objections to justice-based cosmopolitanism. It may well be, as I suggest below, that cosmopolitans will be willing to bite the bullet and accept that the cause of global justice requires the establishment of prima facie dominating institutions, or the undermining of social trust in affluent societies. Nor do these concerns exclude the possibility of a theory of global justice compatible with the republican focus on civic virtue as a solution to the stability problem. They do point, however, to a potential tension between the civic republican account and cosmopolitan theories of social justice. If the civic republican solution to the stability problem is plausible, there is reason to think that the cosmopolitan ideal is not fully justified.

\section{Three Cosmopolitan Objections}

Cosmopolitans about justice would want to resist the conclusion above. In this final section, I turn to consider three cosmopolitan objections to the PMA, which challenge, respectively, the three premises of the argument.

\subsection{Against the motivational precondition premise}

This premise maintains that the normative ideal of social justice requires, as a necessary precondition, a widespread other-regarding motivation among participants in the social scheme in order to be stable. The objections to this premise deny that the stability of the normative ideal is dependent on this motivational precondition.

The first challenge to this premise comes from those who deny that the justification of normative ideals is in any way dependent or constrained by facts about human motivation. One might argue, following G.A. Cohen and David Estlund, that normative ideals can be justified regardless of any facts that pertain to their implementation, and indeed may be held true even

\footnotetext{
${ }^{65}$ See Richard W. Miller, "Cosmopolitan Respect and Patriotic Concern," Philosophy and Public Affairs 27, no. 3 (1998), pp. 210-214.
} 
if they are impossible to implement. ${ }^{66}$ This position is in deep methodological disagreement with the one advanced by the PMA, first and foremost as it presents a radically different understanding of the role of normative political philosophy ${ }^{67}$ While I do not see this as a particularly helpful way of thinking about either political philosophy or social justice, the rejection of this methodological position is well beyond the scope of this article. I am willing to concede, therefore, that social justice as understood by the PMA would not count, in Cohen's terms, as a "fundamental principle of justice", while still maintaining that a conception of social justice is not fully justified unless it can be stable. Some cosmopolitans may wish to endorse Cohen's understanding of justice. However, insofar as cosmopolitans seek to advance a normative, action-guiding theory, with a commitment to a concrete political ideal of the global order, and as such view cosmopolitanism as more than an impossibly utopian ideal in the Cohenite sense, they should not be tempted to follow this line of thought.

This challenge could be formulated more plausibly, however, if it focused on sensitivity not to facts in general, but facts about motivation in particular. Critics may concede that the full justification of normative ideals need to take into account "hard" facts about the world, but that allowing facts about motivation to constrain normative ideals would be capitulating to selfishness or bad faith. ${ }^{68}$ On the level of individual moral duties, it would certainly seem at least prima facie wrong to allow an agent's lack of motivation to constrain what is morally required of her. Yet this is not the challenge posed by the PMA, where the stability problem is the result of a lack of assurance between generally well-motivated individual agents. In other words, the stability problem effects the full justification of cosmopolitanism as a normative political ideal, if not as an ethical ideal. ${ }^{69}$

Daniel Weinstock provides a different, more substantive line of objection when he argues that nationalist theorists "overestimate the degree to which members of national communities agree to the sacrifices that life in a modern democracy involves out of fellow feeling". ${ }^{70}$ These behaviors are always observed within the coercive institutions of the state, which are both responsible for generating and sustaining the appropriate motivations and provide them with content and direction. We simply cannot know how people would act absent these institutions. The PMA cannot, therefore, serve as an argument against cosmopolitanism, because it cannot show that the same political institutions that generate and sustain these behaviors within nation-

\footnotetext{
${ }^{66}$ See Cohen, Rescuing Justice and Equality; David Estlund, "Human Nature and the Limits (If Any) of Political Philosophy," Philosophy \& Public Affairs 39, no. 3 (2011): pp. 207-37; David Estlund, "Utopophobia," Philosophy \& Public Affairs 42, no. 2 (2014): pp. 113-34.

${ }^{67}$ An excellent discussion of this point can be found in Andrew Mason, "What Is the Point of Justice?," Utilitas 24, no. 4 (2012): pp. 525-47.

${ }^{68}$ Estlund "Human Nature"; Holly Lawford-Smith, "Understanding Political Feasibility," Journal of Political Philosophy 21, no. 3 (2013): 243-259; For recent objections to this argument, see David Wiens, "Motivational Limitations on the Demands of Justice," European Journal of Political Theory 15, no. 3 (2016): pp. 333-352; Brian Carey, "Justice for Jerks: Human Nature, Selfishness and Non-Compliance," Social Theory and Practice (forthcoming).

${ }^{69}$ On this distinction, see Edward Hall, "Political Realism and Fact-Sensitivity," Res Publica 19, no. 2 (2012): pp. 173-81.

${ }^{70}$ Daniel Weinstock, “Motivating the Global Demos,” Metaphilosophy 40, no. 1 (2009): pp. 92-108 at p. 93.
} 
states cannot be extended to the global level, relying on analogous global coercive institutions. $^{71}$

Weinstock's argument is well-aimed at versions of the PMA which assume the naturalness of civic motivation, or rely on one some innate idea of natural partiality towards compatriots. This may, then, be a strong argument against the nationalist or the civic humanist anti-cosmopolitan. Yet it does not, I argue, pose a problem for the civic republican version I defend. Civic republicans need not assume the naturalness of civic virtue, and indeed place much emphasis on the transformational power of institutions for citizens' motivation. For this reason, Weinstock's objection, thus understood, does not challenge the republican argument that civic motivation is required for the stability of social justice, only the supposed limits to its scope. This, however, leaves the motivational precondition premise untouched.

A reformulation of this particular objection, while not offered by Weinstock himself, does challenge the motivational precondition premise more explicitly. One may argue that the justification of social justice institutions should not rely on any strong assumptions regarding individuals' other-regarding motives, and that in any case the stability of social justice does not depend on such motives. This is not to say, implausibly, that people are incapable of having such other-regarding motives; but as a methodological point, the theorist need not rely on such assumptions. This argument has a long history in the liberal tradition, from the Enlightenment argument of a "constitution for knaves" which harnesses the avarice of people towards a common good to, the methodological assumptions of social choice theorists. ${ }^{72}$

Once again, I would argue that the civic republican account is better placed to address these objections than the Rawlsian or nationalist accounts, as the relationship between each individual's prudential motives in avoiding domination and the public good is more clearly sustained. In principle, therefore, civic republicanism is not in tension with viewing civic virtue as enlightened self-interest.

Nevertheless, some worries arise when political institutions overtly rely on self-interest alone, even the enlightened kind. First, without internalizing the norms of public culture, compliance becomes conditional on the relative pay-off of defecting. Unless the rewards for compliance or the sanctions for non-compliance are high enough to tilt the balance, they will simply be incorporated into citizens' rational calculations. Second, civic republicans worry that this approach is a self-fulfilling prophecy, since people also value the way they are perceived by others. Viewing citizens as moved by self-interested alone may be damaging for the stability of social institutions, as belief in this fact undermines social trust. ${ }^{73}$ Third, constructing social

\footnotetext{
71 Ibid., 96-100; For a recent extension of this argument, see his "Rooted Cosmopolitanism: Unpacking the Arguments," in Rooted Cosmopolitanism: Canada and the World, ed. Will Kymlicka and Kathryn Walker (Vancouver: UBC Press, 2012), pp. 87-104. Note, however, that this is an independent argument from the one Weinstock has made in earlier writings (see his "National Partiality: Confronting the Intuitions", The Monist, 82 no. 3 [1999]: pp. 516-541).

72 As David Hume writes in his essay "On the Independence of Parliament” (1742): "It is, therefore, a just political maxim, that every man must be supposed a knave; though, at the same time, it appears somewhat strange, that a maxim should be true in politics which is false in fact". For a sophisticated recent version of this line of argument, see Jacob T Levy, “Against Fraternity: Democracy without Solidarity” in Keith Banting and Will Kymlicka (eds.), Solidarity in Diverse Societies, Oxford University Press (forthcoming).

${ }^{73}$ See Lisa Herzog, "Distributive Justice, Feasibility Gridlocks, and the Harmfulness of Economic Ideology," Ethical Theory and Moral Practice, 18, no. 5: pp. 957-969.
} 
institutions for knaves "can have the effect of labelling all relevant parties, including the naturally compliant, as potential deviants." 74 People can no longer expect their compliance to be seen as a result of anything other than a response to incentives, and they may feel alienated and undervalued. Relying instead on civic virtue based on the public culture, with the institutional mechanisms aimed at strengthening it instead of diminishing it, is an instrumentally better way to achieve stable compliance with the social institutions of justice.

\subsection{Against the generating feature premise}

Objections to the generating feature premise concede that social justice requires the widespread existence of civic virtue for the stability of social institutions, but reject the claim that this motivation is necessarily generated by any feature of political society, be it national identity or a historically particular political culture. The source of motivation, instead, lies in the validity of the normative ideal itself. As Habermas's theory of constitutional patriotism is an influential version of this objection, it will be the focus the following discussion. ${ }^{75}$

While national identity was historically important for the rise of the liberal democratic nationstate, Habermas maintains that under current historical conditions it is politically dangerous. Instead of relying on a shared national culture as the source of patriotic allegiance, constitutional patriotism seeks to "uncouple" patriotic loyalty from its particular cultural foundations, whether defined in ethnic national terms or as loyalty to the patrie. The allegiance in patriotism is redirected from the particular institutions and culture of the state to the general principles and values these institutions embody. ${ }^{76}$

The precise challenge of constitutional patriotism to the PMA, however, is not that a common public culture is not necessary for the stability of political institutions. Rather, constitutional patriots argue that this culture must be understood as the particular political manifestation of universal normative values. Insofar as the critique is pointed towards collective identities which are based on ethnic kinship, or substantive ethical accounts of human flourishing, constitutional patriotism and civic republicanism seem to be in agreement. The point of contention, if there is one, lies elsewhere: does the sense of patriotic identification with the political culture reflects primarily an endorsement of the universal principles, represented in contextual practice (as argued by constitutional patriots), or rather an identification with the particular, historically situated way in which these values are manifested (as argued by civic republicans)?

One standard way to reject constitutional patriotism in favor of civic republicanism is to argue that a reliance on universal values as the source of civic virtue would be motivationally impotent. In his critique of Habermas, Viroli argues that " $t]$ he commonality based on shared universal values... is too distant and too general... its chances of winning a rhetorical contest

\footnotetext{
${ }^{74}$ Pettit, Republicanism, p. 219. Bruno Frey, "A Constitution for Knaves Crowds out Civic Virtues," The Economic Journal 107, no. 443 (1997), pp. 1043-1053 at p. 1043.

75 Jürgen Habermas, The New Conservatism: Cultural Criticism and the Historians' Debate (Cambridge: Polity, 1989), pp. 256-262; "Citizenship and National Identity," in Between Facts and Norms: Contributions to a Discourse Theory of Law and Democracy (Cambridge, MA: MIT Press, 1996), pp. 491-516.

${ }^{76}$ See Patchen Markell, "Making Affect Safe for Democracy?: On 'Constitutional Patriotism," Political Theory 28, no. 1 (2000) pp. 38-63 at pp. 41-45; cf. Habermas, The New Conservatism, p. 261. On the similar tensions in Habermas's and Rawls's account of civic motivation, see Sharon Krause, "Desiring Justice: Motivation and Justification in Rawls and Habermas," Contemporary Political Theory 4, no. 4 (2005): pp. 363-85.
} 
do not seem high". ${ }^{77}$ In a similar vein, Bernard Yack and Margaret Canovan argue that Habermas's own account of constitutional patriotism is not as universalist as it claims to be, as it arises as a reaction to a particular national history - in this case, the horrors of German fascism and the re-unification of East and West Germany. ${ }^{78}$ The upshot of this argument seems to be that the supposed universalism of constitutional patriotism is nothing more than particularism in disguise. Constitutional patriotism, therefore, is either too weak or too strong.

This, I believe, is an uncharitable reading of constitutional patriotism, assuming that it is committed to the idea that attachment to general principles must be without reference to political practice or historical particularities, and without being addressed to any particular audience. There is no reason to think this interpretation is correct. As Müller writes, this objection "presumes that some pristine universalism, untainted by particularity of any sort, is actually attainable somehow - and that all else is more or less the same normatively". ${ }^{79}$ I take constitutional patriots to claim, instead, that particular institutional and cultural manifestations of universal values are not replaced by universal values, but are rather constrained by them. In accordance with a recent sympathetic account of constitutional liberalism, this would mean that a "shared experience of history can count as reasons in a civic political community as long as they do not contravene the basic principles of political justice". ${ }^{80}$

This interpretation of constitutional patriotism is what drives the objection to the PMA. However, even in this revised form it still faces a serious problem. Since it turns out that the normative value of motivational attachment to any particular political culture is conditional on its compatibility with independently valid general norms, constitutional patriots seem unable to account for why citizens would ever have an attachment to their particular political culture. Given that the same universally valid principles could be embodied in different institutional contexts, what explains, for example, why a Norwegian would identify with Norway's welfare state rather than Sweden's? If constitutional patriotism is intended to serve as an alternative source of civic motivation, then it is a problem that it cannot provide a conceptually clear account of a citizen's civic motivation towards her own polity. ${ }^{81}$

The civic republican case against constitutional patriotism, therefore, is that it takes for granted an existing bounded political space, or else it is otherwise unable to supply the motivational preconditions for stable political institutions. ${ }^{82}$ Some critics argue that any argument for constitutional patriotism is circular; it needs to be underpinned by a "people" or "transgenerational political community" which recognizes the state as its own, and "thereby

\footnotetext{
77 Viroli, For Love of Country, p. 14.

78 Bernard Yack, "The Myth of the Civic Nation," in Nationalism and the Moral Psychology of Community (Chicago: University Of Chicago Press, 2012), pp. 23-44; Margaret Canovan, "Patriotism Is Not Enough," British Journal of Political Science 30, no. 3 (2000), pp. 413-32.

${ }^{79}$ Jan-Werner Müller, "Seven Ways to Misunderstand Constitutional Patriotism," Notizie Di POLITEIA, no. 96 (2009), pp. 20-24 at p. 22.

${ }^{80}$ Justine Lacroix, "For a European Constitutional Patriotism," Political Studies 50, no. 5 (2002), pp. $944-958$ at p. 950 ,

${ }^{81}$ For an excellent discussion of this critique, See Anna Stilz, Liberal Loyalty: Freedom, Obligation, and the State (Princeton, NJ: Princeton University Press, 2009), pp. 137-73.,

${ }^{82}$ Here I am relying on Jan-Werner Müller, Constitutional Patriotism (Princeton, NJ: Princeton University Press, 2007), p. 68; cf. Laborde, "From Constitutional to Civic Patriotism," pp. 595-596.
} 
confer upon it the legitimacy and power it needs". ${ }^{83}$ Civic republicans need not go that far in exaggerating the difference between their position and constitutional patriotism; nor must they claim that the requirement of a historically embedded political culture assumes either an uncritical endorsement of this culture or the historical process that brought it about. ${ }^{84}$ On the contrary: a good republican citizen must adopt a critical stance towards the political culture and political institutions of her country, because they are hers. The patriotic slogan, "my country, right or wrong", is thus interpreted not as blind loyalty to state institutions, but as a civic obligation towards immanent critique. Nevertheless, even this critical variation sees civic virtue as attached to a particular public culture.

\subsection{Against the factual claim}

Suppose then that opponents of the PMA concede the first two premises: social justice requires widespread civic motivation to be stable, and this can only be generated and sustained by a shared political culture. Even conceding these points, the argument remains vulnerable to refutations of it factual claim; this premise, recall, maintains that a political culture and collective identity (the generating feature F) does not exist beyond bounded societies. There are two ways to object to this premise. The first is to challenge its empirical basis, and argue that a global public culture, a collective identity, or something relevantly similar, already exists. The second is to argue that a global public culture is not conceptually impossible, and therefore the PMA is unjustifiably status-quo biased.

In the first version of this objection, critics point to three sources leading to the emergence of global, supranational and transnational forms of political cultures and allegiances. First, they point to supranational political institutions, most prominently the European Union, as generating a new sense of political identity and solidarity beyond the nation-state; Second, they point to the effects of new forms of global cultural influences, economic transactions and media representation on the social identities of individuals worldwide, leading them to see themselves increasingly as "citizens of the world"; And third, they point to social phenomena such as dual nationals, diaspora communities and international migration as transnational sources for global solidarity which subverts the paradigmatic state-bounded political community.

These empirical developments are undeniable, and have significant political and normative implications. However, it is not obvious that the most plausible interpretation of these phenomena poses a challenge to the factual claim made by the PMA. Take for example the European Union. While the idea of an 'ever close union' is central to this institution, and despite theoretical and philosophical support for the idea of a "European People", the data is far from clear: Only $2 \%$ of EU citizens view themselves as primarily "Europeans", and only $6 \%$ regard their European identity more important than their national identity. ${ }^{85}$ Globally speaking, only $7.8 \%$ of those surveyed in a recent research report that their sense of belonging is to "the world

\footnotetext{
${ }^{83}$ Canovan, "Patriotism Is Not Enough," p. 422; pp. 426-427; Bernard Yack, "The Myth of the Civic Nation".

${ }^{84}$ Mason, Community, Solidarity and Belonging, p. 137; Laborde, "From Constitutional to Civic Patriotism," pp. 595-596

${ }^{85}$ Standard Eurobarometer 83, Spring 2015, http://ec.europa.eu/public_opinion/archives/eb/eb83/eb83 en.htm [accessed 25th July 2016].
} 
as a whole". ${ }^{86}$ Some suggest that these sentiments are on the rise, and perhaps they are. But they do not support the claim that a global equivalent to the political identity of bounded communities currently exists.

One may argue, of course, that these public opinion polls should be taken with a healthy dose of skepticism; even if we can be certain that all respondents' understanding of the question is similar, this at most reflects their subjective sense of identity, and not the objective sense in which their habits, relationships and behaviors have changed. ${ }^{87}$ Yet it is important to reiterate here that civic republicans' central claim is not that people do not, or cannot, have multiple allegiances, conflicting values, or ethical views that extend beyond the boundaries of the state. The argument, rather, is that even if some individuals hold these views, the existence of a shared political culture and identity within the state generates and sustains the necessary trust and solidarity for the stability of social justice.

Perhaps this reply is overly status-quo biased, and cosmopolitans need only demonstrate that a global political culture of the relevant kind is feasibly achievable, not that it currently exists. Unless we take the view that the different political cultures of the world are intrinsically incompatible, we have no reason to deny the possibility that existing cultural differences would become irrelevant to the question of political identity, much in the same way ethnic and religious difference have (albeit imperfectly) become within the national context. And certainly globally shared identity is not conceptually impossible. ${ }^{88}$ As I argued above, civic republicans see political culture as the result of an historical political process, so solidarity between compatriots cannot be argued to be "natural". Why must we think that these processes are impossible beyond the boundaries of the nation state? ${ }^{89}$

This is the strongest argument against the PMA, but it is not necessarily a fatal one. While the technical feasibility of a global public culture is beyond question, one may raise questions about the normative feasibility of the project, that is, the moral costs involved in collective identity construction. ${ }^{90}$ Analytically, at least three categories of moral costs are relevant with regards to the cosmopolitan end-state - that is, a world in which a cosmopolitan equivalent to a collective political identity exists:

1. Moral costs of the cosmopolitan end-state itself.

\footnotetext{
${ }^{86}$ World Values Survey 6 (2010-2014), at http://www.worldvaluessurvey.org/WVSDocumentationWV6.jsp [accessed 23rd May 2016]. Moreover, the data suggests - perhaps unsurprisingly - that both in the European case and the global case, these sentiments are more common amongst the young, wealthy and educated. See Craig J. Calhoun, "The Class Consciousness of Frequent Travelers: Toward a Critique of Actually Existing Cosmopolitanism," The South Atlantic Quarterly 101, no. 4 (2002): pp. 869-97.

${ }^{87}$ I thank an anonymous reviewer for pressing me on this point.

${ }^{88}$ See Arash Abizadeh, "Does Collective Identity Presuppose an Other? On the Alleged Incoherence of Global Solidarity," American Political Science Review 99, no. 1 (2005): pp. 45-60 at p. 48

${ }^{89}$ See Charles R. Beitz, "Cosmopolitan Ideals and National Sentiment," The Journal of Philosophy 80, no. 10 (1983), pp. 591-600; Simon Caney, Justice beyond Borders (Oxford: Oxford University Press, 2006), pp. 133134, 175; Kok-Chor Tan, Justice without Borders: Cosmopolitanism, Nationalism, and Patriotism (Cambridge: Cambridge University Press, 2004), p. 104.

${ }^{90}$ The following is an expansion of my discussion in Lior Erez, "Cosmopolitanism, Motivation, and Normative Feasibility," Ethics \& Global Politics 8, no. 1 (2015): 43-55.
} 
2. Moral costs of transitioning to a cosmopolitan identity.

3. Moral opportunity costs of trying to create a cosmopolitan identity.

The first category refers to the cost that will be incurred were the cosmopolitan world to become a reality. As nationalist and communitarian critics argue, a single global political culture would involve the dissolution of particularistic identities, which is a loss in two ways: first, because these identities are valuable in themselves, and second, because a plurality of particularistic identities is valuable. ${ }^{91}$ This objection is not entirely open to civic republicans, however: as was indicated above, political culture in civic republicanism is not an all-encompassing practical identity, and is fully compatible with diverse private and communal conceptions of the good, to be protected by the status of citizenship. An all-encompassing cosmopolitan political identity would possibly remain objectionable due to its dominating potential, but cosmopolitans are not required to endorse such end-goal.

Nevertheless, even if we reject the first category of moral costs, this does not imply that costs of transition may be disregarded. I here follow Juha Räikkä and Alan Buchanan in arguing that "moral accessibility" is a necessary desideratum of a normative theory: the ideal state of affairs, desirable as it may be in itself, must not be achieved through actions that would be morally too costly. ${ }^{92}$ Indeed, precisely given that national cultures and identities are socially constructed should lead to doubt whether this process could be morally justifiable. The historical process in which really existing collective political identities were constructed involved what today would be considered serious violations of human and minority rights. These included, to name but a few practices: the promotion of false national myths; forced suppression of local cultures and languages; wars of dominance between competing ethnic groups; and in some extreme cases, forced relocation of populations.

I am not suggesting, of course, that the construction of a global political identity must follow the bloody history of nation building. First, even if this were the case, cosmopolitans may plausibly argue that these costs, while real, are justified all things considered. Cosmopolitans may also rightly point out to more acceptable paths of collective identity formation, such as cosmopolitan education or market-led integration. ${ }^{93}$ One may be sceptical with regards to the achievability and stability of these strategies on a global scale - as I argued above, their success even in the relatively integrated, culturally similar and heavily funded project of a European Identity is a mixed bag - but this should not, in itself, preclude the duty of attempting to do so.

\footnotetext{
${ }^{91}$ David Miller, “Cosmopolitanism: A Critique," Critical Review of International Social and Political Philosophy 5, no. 3 (2002): pp. 80-85 at p. 84.

92 Juha Räikkä, “The Feasibility Condition in Political Theory,” Journal of Political Philosophy 6, no. 1 (2002), pp. 27-40; Alan Buchanan, Justice, Legitimacy, and Self-Determination: Moral Foundations for International Law (New York, NY: Oxford University Press, 2004), pp. 60-61.

93 On cosmopolitan education see, for example, Martha Nussbaum, Political Emotions: Why Love Matters for Justice (Cambridge, MA: Harvard University Press, 2013), chap. 8. It should be noted, however, that Nussbaum perceives this as a transformation of existing patriotic identities, as opposed to a creation of a new global identity. As such, this is fully compatible with civic republicanism. See Erez, "Cosmopolitanism, Motivation, and Normative Feasibility," p. 51.
} 
This leads to the third category, which could be best described as one of moral opportunity costs. ${ }^{94}$ Even morally innocuous paths towards a global political culture would require resources, political engagement, a reorientation of institutional focus, and sustaining effort. While different political identities do not necessarily exist in a zero-sum game, it would be foolish to ignore that, as some cosmopolitans argue, the construction and maintenance of national identities require the weakening of cosmopolitan identification, just as the construction and maintenance of cosmopolitan identity will weaken national identification. ${ }^{95}$ Given the uncertainty of constructing a global political culture, attempting to create a global analogue of the domestic political culture, and failing, may undermine the motivational basis for social justice where it currently (if imperfectly) exists. The republican concern here is that not only will cosmopolitan identity construction fall short of providing the motivational basis for the sacrifices required by social justice, for the reasons discussed above, but in addition its construction will undermine the motivational efficacy of local political identities. ${ }^{96}$ While currently existing political identities may have been formed illiberally, and would, in an ideal world, cease to exist, they are for better or for worse central loci of group solidarity necessary to the advancement of social justice.

\section{Concluding Remarks}

Civic republicanism provides the most plausible interpretation of the political motivation objection to cosmopolitanism. It is therefore the argument that cosmopolitans need to refute in order to sustain their position as a robust political ideal. As I have shown in the last section of this article, the most promising route for cosmopolitans towards this end would be to challenge the factual claim at the heart of the PMA and argue that even if a global public culture does not currently exist, it might exist. In these concluding remarks, I would like to consider the implications of this move for cosmopolitan theory.

The main implication of this argument is that, given the cumulative weight of the three categories of moral costs, cosmopolitans should provide a motivational basis for stable institutions that mitigates these costs, or else they remain susceptible to the objection made by civic republicanism. Whether such route exists is an open question, and it has been somewhat of a blind spot for liberal cosmopolitan theorists. This may be changing, as recent contributions to the global justice literature have placed more emphasis on institutional stability more generally, and on political motivation more specifically. For these positions, my argument here should be seen as a friendly amendment, clarifying the best interpretation of the problem they aim to address, and leading to stable institutional answers to the most pressing global ethical and political questions. ${ }^{97}$

\footnotetext{
94 Carmen Pavel, “Cosmopolitanism, Nationalism and Moral Opportunity Costs,” Polity 41, no. 4 (2009), pp. 489-513.

${ }^{95}$ See David V. Axelsen, “The State Made Me Do It: How Anti-Cosmopolitanism Is Created by the State,” Journal of Political Philosophy 21, no. 4 (2013): pp. 451-72.

${ }^{96}$ Miller, “Cosmopolitan Respect and Patriotic Concern,” pp. 210-219.

${ }^{97}$ See for example Lea Ypi, Global Justice and Avant-Garde Political Agency (Oxford: Oxford University Press, 2012); Miriam Ronzoni, "Two Conceptions of State Sovereignty and Their Implications for Global Institutional Design,” Critical Review of International Social and Political Philosophy 15, no. 5 (2012): 573-91,; Cécile Laborde and Miriam Ronzoni, "What Is a Free State? Republican Internationalism and Globalisation," Political Studies, 64, no. 2 (2016): pp. 279-296. Terry Macdonald, "Cosmopolitan Political Institutions," in The Politics of Compassion, ed. Michael Ure and Mervyn Frost (Routledge, 2014), pp. 82-97.
} 
This reorientation of focus by cosmopolitan theorists is important especially given the alternatives. If no route to cosmopolitanism that mitigates its costs is suggested, cosmopolitan theory is faced with a difficult dilemma: either bracket away the question of political implementation, thus treating cosmopolitanism as a moral ideal with little practical significance, or radicalize it, arguing that the potential costs of creating a global political culture are outweighed by the severe injustice of the current world order. ${ }^{98}$ While this last option would require a considerable shift in cosmopolitan theory, it is certainly not without appeal. The upshot of my account, in this case, would be as a plea for consistency; if real cosmopolitanism requires such radical trade-offs, these implications need to at least be made explicit. ${ }^{99}$

${ }^{98}$ For a recent statement of this position, see Richard J. Arneson, "Extreme Cosmopolitanisms Defended," Critical Review of International Social and Political Philosophy, (forthcoming),

${ }^{99}$ I would like to thank Richard Bellamy and Cécile Laborde for their comments and guidance on my doctoral project, from which this paper originates. Many thanks as well to the editors and referees at Social Theory and Practice for their constructive and challenging feedback, which greatly improved the paper. Earlier versions of the article were presented at the UCL Political Theory Workshop (December 2013), Brave New World Postgraduate Conference at the University of Manchester (June 2013), Academia.edu online session (August 2015), and the Postdoctoral Political Thought Forum, University of Cambridge (December 2015). I would like to thank all of the participants for their comments, and in particular Sara Amighetti, David Axelsen, Brian Carey, Laura Lo Coco, Karin Kuhlemann, Nick Martin, Luke Ulaş, and Sam Zeitlin for providing written comments and critiques. Special thanks to Alasia Nuti for her ongoing support. Funding for the research period in which the early version of this article was written was provided by the UCL Overseas Trust and the Anglo-Israel Association's Kenneth Lindsay Scholarship. 